\title{
Sputter-Deposited Cr-Ag Films for Environmental Antimicrobial Applications
}

\author{
Lijun Wang ${ }^{1}$, Yingjie Wang ${ }^{1}$, Powan Shum ${ }^{2}{ }^{-}$, Yuefeng Hou ${ }^{3, *}$ and Tao Fu ${ }^{1, *(D)}$ \\ 1 Key Laboratory of Biomedical Information Engineering of Ministry of Education, School of Life Science and \\ Technology, Xi'an Jiaotong University, Xi'an 710049, China; jun411better@stu.xjtu.edu.cn (L.W.); \\ ying973500@stu.xjtu.edu.cn (Y.W.) \\ 2 Asahi Group Co. Ltd., Kwun Tong, Hong Kong, China; mepwshum@hotmail.com \\ 3 Guang Dong Cenfly Medical Technology Co. Ltd., Jiangmen 529200, China \\ * Correspondence: 13928241393@139.com (Y.H.); taofu@xitu.edu.cn (T.F.)
}

check for

updates

Citation: Wang, L.; Wang, Y.; Shum,

P.; Hou, Y.; Fu, T. Sputter-Deposited Cr-Ag Films for Environmental Antimicrobial Applications. Coatings 2021, 11, 1153. https://doi.org/ 10.3390/coatings11101153

Academic Editor: Cecilia Mortalò

Received: 26 August 2021

Accepted: 9 September 2021

Published: 23 September 2021

Publisher's Note: MDPI stays neutral with regard to jurisdictional claims in published maps and institutional affiliations.

Copyright: (c) 2021 by the authors. Licensee MDPI, Basel, Switzerland. This article is an open access article distributed under the terms and conditions of the Creative Commons Attribution (CC BY) license (https:// creativecommons.org/licenses/by/ $4.0 /)$.

\begin{abstract}
Chromium-silver films with $\leq 39.2$ at.\% Ag were deposited by magnetron sputtering for antibacterial applications. X-ray diffraction and scanning electron microscopy analyses indicate that the films consist of $\mathrm{Cr}$ and $\mathrm{Ag}$, and silver segregation is not obvious at the surface. The films are hard (628-968 $\left.\mathrm{HV}_{0.001}\right)$ and hydrophobic with low surface energy $\left(12.8-26.8 \mathrm{~mJ} / \mathrm{m}^{2}\right)$. The drying time of water droplets is dependent on ambient conditions, material wettability and droplet size. The test against Escherichia coli indicates antibacterial ratios of $100 \%$ for the $\mathrm{Cr}-\mathrm{Ag}$ films (action time $3 \mathrm{~h}$ ). However, bacteria died within $15 \mathrm{~min}$ due to quick drying of the bacterial suspension in open ambient conditions. The $\mathrm{Cr}-\mathrm{Ag}$ films would have potential antimicrobial applications in public environmental facilities.
\end{abstract}

Keywords: sputter; Cr; film; silver; antimicrobial

\section{Introduction}

Bacteria and virus-related infections continue to be a major public health problem in hospitals, healthcare units and other public spaces [1-4]. It is of crucial importance to impede the spread of unwanted bacteria and viruses in clinical and environmental circumstances. Over 20 metallic elements have been studied for antimicrobial property [5,6], in which $\mathrm{Ag}, \mathrm{Cu}, \mathrm{Zn}$, etc are demonstrated to possess good microcidal activity [1,6-9]. In particular, silver as a historic and effective antimicrobial agent has a wide spectrum against many drug-resistant bacteria [10] and a fairly good compatibility with mammalian cells. However, the high price and low hardness are its demerits.

In the vapor deposition techniques, magnetron sputtering is capable of producing multi-element coatings with even nanocomposite structures and it can be scaled up for industrial applications. Vapor deposited silver-containing ceramic coatings such as $\mathrm{Ta}_{2} \mathrm{O}_{5}-$ $\mathrm{Ag}$ [11], zirconium carbonitride ( $\mathrm{ZrCN})-\mathrm{Ag}$ [12] and diamond-like carbon (DLC)-Ag films [13-15] have high hardness and good antibacterial properties. However, silver segregation often occurs for these composite coatings [11-15] and it increases the biocompatibility concern of silver. Thus, transition metal-silver films are developed for antibacterial applications, including Ti-(Cu)-Ag, Nb-Ag and $\mathrm{W}-\mathrm{Ag}$ films [10,16-18].

Metallic chromium $(\mathrm{Cr})$ is a silver-white, hard and corrosion-resistant metal. Electrochemically deposited $\mathrm{Cr}$ films are widely used for decoration and surface hardening utilities. Chromium is also involved in stainless steels and $\mathrm{CoCr}$ alloys as an alloying element for biomedical, environmental, home and other applications. Although $\mathrm{Cr}$ is regarded as a biologically toxic element, it is actually a necessary trace element with multiple biological functions. Hexavalent chromium has significant toxicity, while metallic, trivalent and other valence chromium is not harmful. It is of great interest to develop $\mathrm{Cr}-\mathrm{Ag}$ films for 
antimicrobial applications $[19,20]$. For the coating preparation techniques, the clean process of vapor deposition can avoid the environmental problems caused by electroplating.

Recent studies have shown that the antibacterial properties of the materials are not only dependent on their chemical composition, but also related to the microstructure, surface characteristics, environmental conditions and other factors [1,3,4,21]. Researchers have developed antibacterial experiment methods simulating breathing, speaking, coughing, sneezing, sweat contact and other conditions [1-3]. The drying process of liquid droplets is affected by the material composition, wettability and environmental conditions [3,4,22]. In this work $\mathrm{Cr}-\mathrm{Ag}$ films with $\mathrm{Ag}$ content up to 39.2 at.\% were deposited by the magnetron sputtering technique, and microstructure, hardness, wettability, water droplet drying process and antibacterial properties of the films were investigated.

\section{Experimental}

\subsection{Samples Preparation}

The $\mathrm{Cr}-\mathrm{Ag}$ films were deposited on glass slides and silicon (100) wafers by a magnetron sputtering system. The substrates were degreased, ultrasonically cleaned and blown dry in flowing nitrogen gas in subsequence. In the sputtering system, two chromium elemental targets and one silver target (purity $>99.9 \%$ ) were fixed for the deposition of $\mathrm{Cr}-\mathrm{Ag}$ films. The substrates were mounted on the substrate holder that was rotated at a speed of $10 \mathrm{rpm}$. The vacuum chamber was evacuated and then pure Ar working gas (99.999\% purity) was introduced. After plasma ion etching, the films were deposited with the $\mathrm{Cr}$ targets current of $4.0 \mathrm{~A}$, the silver target current of 0-2.0 A, the bias of $-60 \mathrm{~V}$ and the deposition time of 15-30 min. The $\mathrm{Cr}-\mathrm{Ag}$ film samples were noted as SX, in which $\mathrm{X}$ meant silver content measured by energy-dispersive X-ray (EDX) analysis (Table 1).

Table 1. Silver target current $\left(\mathrm{I}_{\mathrm{Ag}}\right)$, deposition time $(\mathrm{t})$, deposition rate $(\mathrm{R})$, silver content $([\mathrm{Ag}])$, grain size $(\mathrm{d})$ and contact angle (CA) of the samples.

\begin{tabular}{|c|c|c|c|c|c|c|c|c|}
\hline \multirow{2}{*}{ Sample } & \multirow{2}{*}{$\begin{array}{l}\mathrm{I}_{\mathrm{Ag}} \\
\text { (A) }\end{array}$} & \multirow{2}{*}{$\begin{array}{c}\mathrm{t} \\
(\mathrm{min})\end{array}$} & \multirow{2}{*}{$\begin{array}{c}R^{+} \\
(\mathrm{nm} / \mathrm{min})\end{array}$} & \multirow{2}{*}{$\begin{array}{c}{[\mathrm{Ag}]^{+}} \\
\text {at. } \%\end{array}$} & \multirow{2}{*}{$\begin{array}{c}\mathrm{d}^{*} \\
(\mathrm{~nm})\end{array}$} & \multicolumn{3}{|c|}{$\mathrm{CA}\left({ }^{\circ}\right)^{*}$} \\
\hline & & & & & & Water & Suspension & Glycol \\
\hline Glass & / & / & / & / & / & $49.1 \pm 2.3$ & $44.7 \pm 1.5$ & $44.5 \pm 3.8$ \\
\hline Steel & / & / & / & / & / & $91.1 \pm 3.1$ & $89.4 \pm 2.8$ & $72.7 \pm 0.5$ \\
\hline S0 & 0 & 30 & 21.7 & 0 & 27 & $107.2 \pm 0.3$ & $95.8 \pm 1.2$ & $81.7 \pm 2.1$ \\
\hline $\mathrm{S} 1.8$ & 0.4 & 30 & 26.3 & 1.8 & 18.9 & $117.9 \pm 0.9$ & $118.8 \pm 2.3$ & $97.3 \pm 2.3$ \\
\hline S5.8 & 0.6 & 30 & 27.3 & 5.8 & 18.7 & $120.1 \pm 0.1$ & $121.4 \pm 0.2$ & $89.9 \pm 3.6$ \\
\hline S15.0 & 1.0 & 25 & 32.0 & 15.0 & 12.7 & $113.8 \pm 1.3$ & $117.2 \pm 1.4$ & $94.6 \pm 5.2$ \\
\hline S27.7 & 1.5 & 20 & 37.0 & 27.7 & 9.5 & $100.5 \pm 0.9$ & $105.4 \pm 0.4$ & $76.3 \pm 1.3$ \\
\hline S39.20 & 2.0 & 15 & 60.7 & 39.2 & 9.2 & $102.9 \pm 2.2$ & $110.3 \pm 1.6$ & $81.5 \pm 3.4$ \\
\hline Silver & 2.0 & 30 & 25.0 & 100 & / & $91.6 \pm 2.8$ & $96.3 \pm 2.2$ & $67.3 \pm 0.8$ \\
\hline
\end{tabular}

${ }^{+}$: samples with $\mathrm{Si}(100)$ substrate, ${ }^{*}$ : samples with glass substrate, suspension: Escherichia coli cells suspension $\left(10^{5} \mathrm{cfu} / \mathrm{mL}\right)$.

\subsection{Material Characterization and Tests}

Phase structure of the coated samples was analyzed by X-ray diffraction (XRD, X'Pert PRO, PANalytical, Almelo, The Netherlands, $\mathrm{CuK} \alpha$ ). The surface morphology of the coated samples was examined by scanning electron microscopy (SEM, Quanta 600F, FEI Co., Hillsboro, OR, USA) equipped with EDX analysis. The thickness of the films was obtained by measuring the step height with a stylus surface profiler (DektakXT, Bruker Daltonics Inc., Billerica, MA, USA, vertical resolution $0.1 \mathrm{~nm}$, stylus radius $5 \mu \mathrm{m}$ ).

The microhardness of the coatings was measured by Fischerscope HM2000 (Fischer Instrumentation Ltd., Sindelfingen, Germany, Vicker's diamond pyramid indenter, test load $10 \mathrm{mN}$ ). The wettability of the samples was assessed by measuring water and glycol contact angles using a contact angle goniometer (JY-82A, Dingsheng Testing Equipment Co. Ltd, Chengde, China, drop volume $5 \mu \mathrm{L}$ ) under ambient conditions. The surface energy of the samples was determined from the above contact angles with the method based on 
Owens -Wendt theoretical model $[15,18]$. A water droplet $(2 \mu \mathrm{L})$ was dropped, or a layer of water film was sprayed on the sample surface, and the water drying process was observed with an optical microscope.

\subsection{Antibacterial Test}

The antibacterial property of the samples was assessed by the agar plate counting method against Escherichia coli (E. coli, CMCC (B) 44102), which is a typical kind of environmental and pathogenic bacteria. The samples were sterilized with UV light for $30 \mathrm{~min}$ per side. Then, $10 \mu \mathrm{L}$ of $E$. coli suspension (concentration $10^{5} \mathrm{cfu} / \mathrm{mL}$ ) was dropped onto the film surface of the samples, and the surface was covered soon by a piece of the sterile filter membrane. After being placed in the dark at room temperature for 15, 30, 60 and $180 \mathrm{~min}$, the samples were rinsed with $3 \mathrm{~mL}$ sterile water to collect the survival bacteria. After stirring by a vortex mixer for $1 \mathrm{~min}, 100 \mu \mathrm{L}$ of the suspension was dropped on the preformed Luria-Bertani agar plate and spread evenly using a sterile spreader. The inoculums were cultured aerobically at $37^{\circ} \mathrm{C}$ for $24 \mathrm{~h}$ for observation. The samples were tested at least twice independently. The above $E$. coli suspension $(5 \mu \mathrm{L})$ was also injected onto the surface of as-deposited samples to measure the contact angles.

\section{Results and Discussion}

\subsection{Structural Analyses}

The $\mathrm{Cr}-\mathrm{Ag}$ films on glass and silicon substrates are adherent and smooth. The microstructure of the $\mathrm{Cr}-\mathrm{Ag}$ films with glass substrate was analyzed by XRD (Figure 1). In the patterns, $\mathrm{Cr}$ peaks are detected for all samples, and the strong $\operatorname{Cr}(110)$ peaks indicate the columnar structure of the films. A weak peak from silver (111) plane appears at $2 \theta=38.3^{\circ}$ when silver is added into the films S1.8-S15.0, and this peak is strong for samples S27.7 and S39.2. The $\mathrm{Cr}(110)$ peak moves to lower $2 \theta$ angles (e.g., $44.1^{\circ}$ ) possibly due to stress release of the films by soft silver phase, and the $\operatorname{Ag}(200)$ peak located at $2 \theta=44.6^{\circ}$ is apparent for samples S5.8-S39.2. Thus, the films are composed of $\mathrm{Cr}$ and Ag phases for samples S1.8-S39.2.

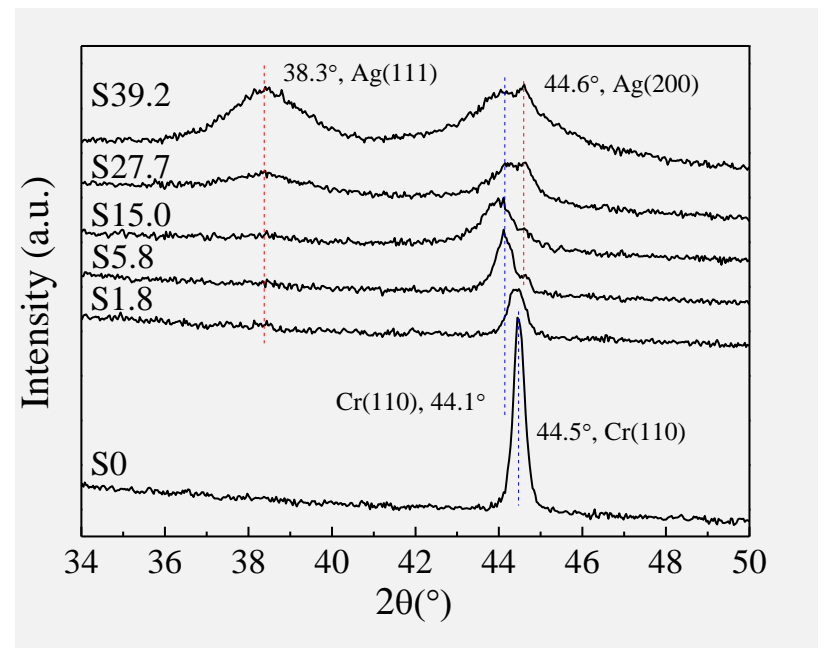

Figure 1. XRD patterns of the $\mathrm{Cr}-\mathrm{Ag}$ film samples with glass substrate.

SEM surface images of the samples with glass substrate are shown in Figure 2. Nanograins with facets are observed for sample S0-S15.0, and the surface becomes blurred and mound-like for samples S27.7 and S39.2. The surface change is related to film structural evolution, which is reflected by the widened $\operatorname{Ag}(111)$ and $\operatorname{Cr}(110)$ peaks and the reduced Cr grain size calculated using Debye-Scherrer equation (Table 1). Sparse silver particles appear at the surface of sample S27.7, and their density is much lower than those on DLC-Ag films [13]. The serious silver segregation at the surface from ceramic matrix does not occur for the Cr-Ag films. 


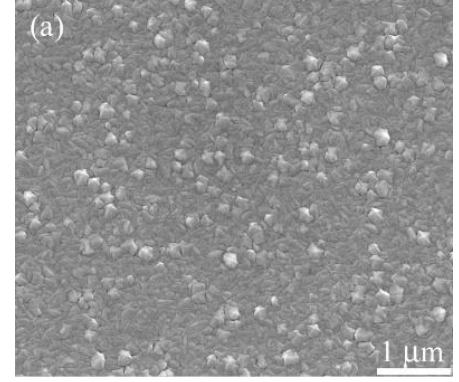

(a)

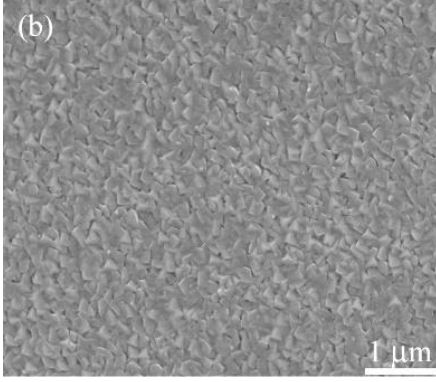

(b)

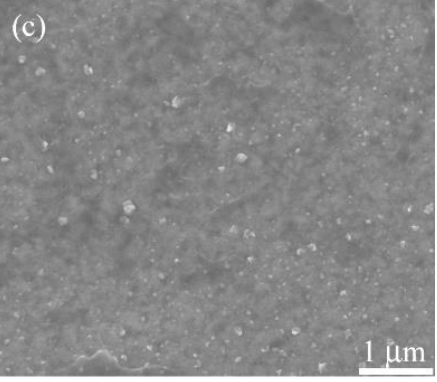

(c)

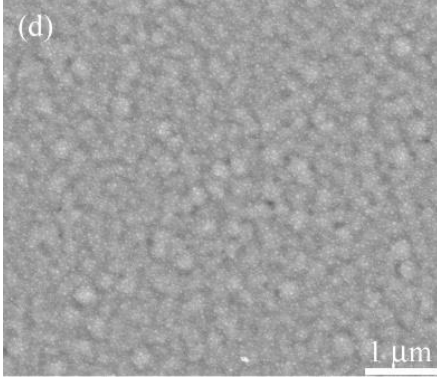

(d)

Figure 2. SEM surface images of the Cr-Ag films with glass substrate: (a) S0, (b) S15.0, (c) S27.7, (d) S39.2.

The film thickness was $0.65-0.91 \mu \mathrm{m}$ measured by the surface profiler, and the deposition rate increases with silver target current, ranging from $21.7 \mathrm{~nm} / \mathrm{min}$ for pure $\mathrm{Cr}$ film to $60.7 \mathrm{~nm} / \mathrm{min}$ for S39.2 film (Table 1).

\subsection{Hardness and Wettability Tests}

The hardness of the films on silicon substrate was measured by a microhardness tester. The hardness of the pure $\mathrm{Cr}$ film is $994 \mathrm{HV}_{0.001}$, and the hardness of the $\mathrm{Cr}-\mathrm{Ag}$ composite films ranges from 628 to $968 \mathrm{HV}_{0.001}$. These hardness values are much higher than those of stainless steel ( 250 HV) and pure Ag film $(240 \mathrm{HV})$. The hard $\mathrm{Cr}-\mathrm{Ag}$ films will enhance the wear resistance of the coated stainless steel substrate.

The wettability of a material is determined by its chemical nature, surface groups, surface roughness and other factors. The $\mathrm{Cr}-\mathrm{Ag}$ film samples are hydrophobic, with high water contact angles (100.5-120.1 ${ }^{\circ}$, Table 1). Vapor deposited Cr-based films are often reported to exhibit hydrophobic behavior together with low surface energy $[23,24]$. The silver film sample is also hydrophobic $\left(91.6^{\circ}\right)$, agreeing with the literature report [25]. The E. coli cells suspension and glycol have also high contact angles at the surface of both kinds of films (Table 1).

The calculated surface energy values are shown in Figure 3. The hydrophilic slide glass has high surface energy with the polar component being dominant, and the hydrophobic stainless steel and coating samples have relatively low values with the dispersive one being dominant. It was reported that the hydrophobic surface with low surface energy is beneficial for anti-fouling and antimicrobial properties $[15,26,27]$, while a hydrophilic surface with high surface energy is favorable for cell attachment [28].

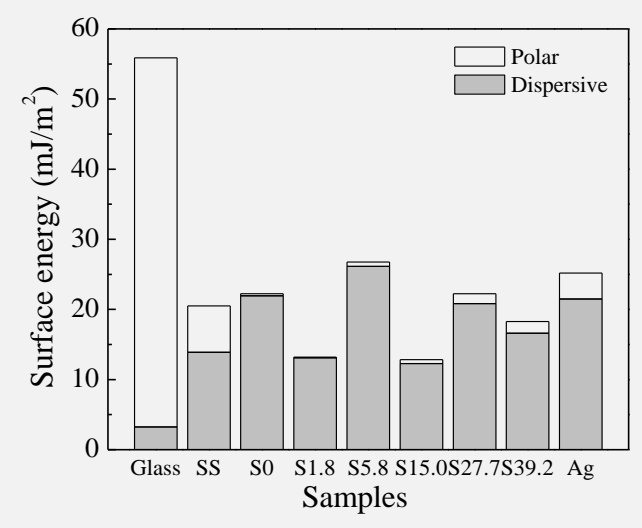

Figure 3. Surface energy of the glass, stainless steel, $\mathrm{Cr}-\mathrm{Ag}$ and $\mathrm{Ag}$ film samples.

Liquid evaporation is a common phenomenon in different industries. Water vaporizing rate at the surface, $W$ can be described as $W=a t^{b} v^{d} / p^{c} H^{e}$ by the multivariate nonlinear regression analysis modeling [29], in which $t$ is temperature, $v$ is air flow rate, $p$ is pressure, $H$ is humidity, and $a-e$ are the regression coefficients. Therefore, a water 
droplet dries more quickly at higher temperatures and lower humidity. The drying process of a $2 \mu \mathrm{L}$ water droplet on the sample surface was observed with an optical microscope at constant ambient conditions (Figure $4 a, b$ ). Due to the smaller surface area of the droplets on $\mathrm{Cr}-\mathrm{Ag}$ films, they dried more slowly than that on the glass substrate (Figure 5).
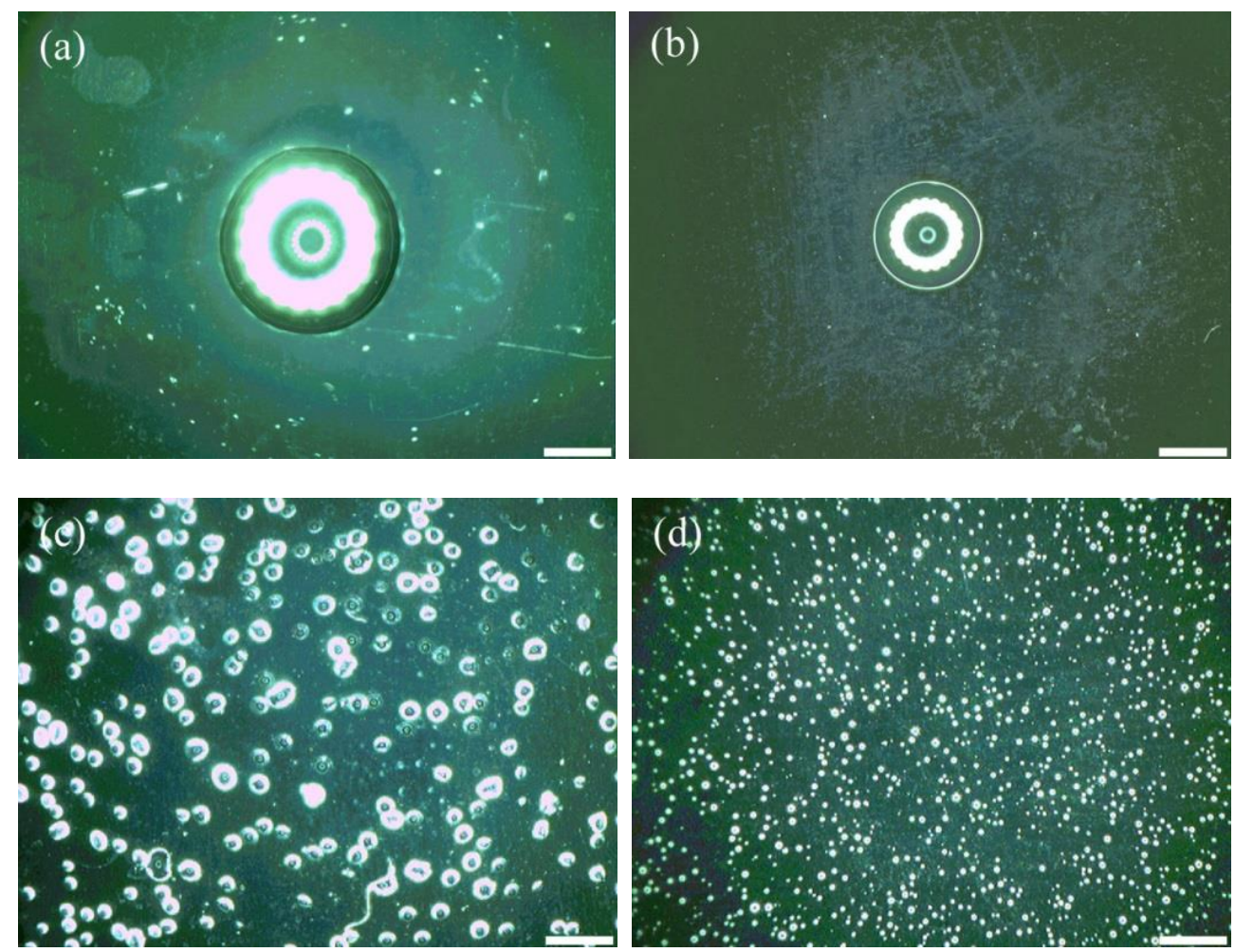

Figure 4. Representative top view images of $2 \mu \mathrm{L}$ water droplet and sprayed water film on (a,c) glass and $(\mathbf{b}, \mathbf{d})$ film sample 55.8 , respectively (bar $=1 \mathrm{~mm})$.

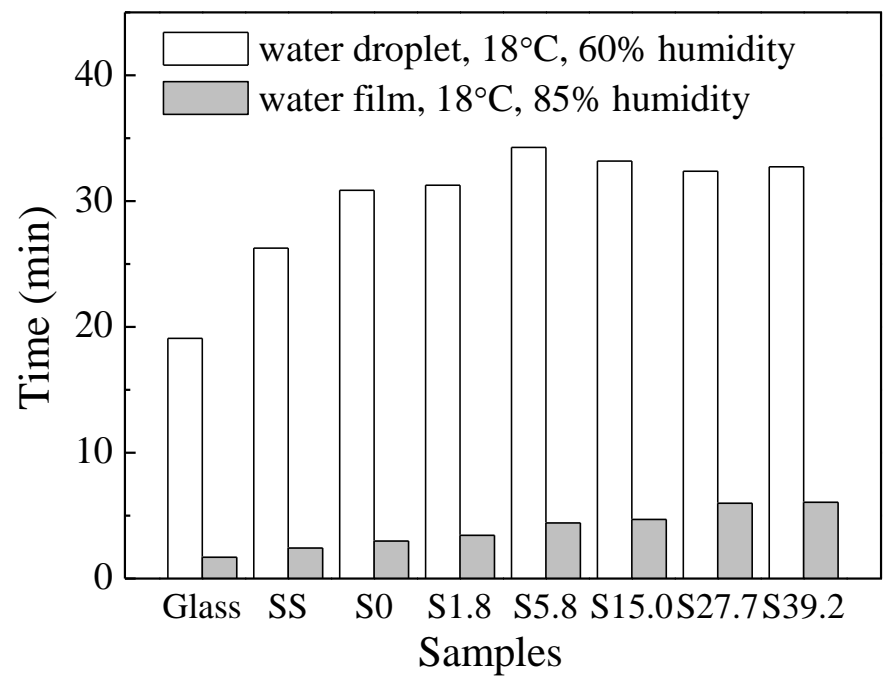

Figure 5. The drying time of $2 \mu \mathrm{L}$ water droplet and the sprayed water film on glass and $\mathrm{Cr}-\mathrm{Ag}$ film samples.

A layer of water film was sprayed on the surface of glass and film samples to simulate the drying process of droplets on materials in the cases of sneezing and coughing [2,3], where the liquid droplets are commonly smaller than $100 \mu \mathrm{m}$. Under the same preparation conditions, large water droplets $(220-350 \mu \mathrm{m})$ are formed on the glass surface, while many fine water dots $(70-160 \mu \mathrm{m}$, largely $<100 \mu \mathrm{m})$ are formed on the film surface (Figure $4 \mathrm{c}, \mathrm{d}$ ). 
The water layers on the film surface have a longer drying time than that on the glass surface, which is consistent with the observation of a single droplet (Figure 5). Because the sprayed water droplets are much smaller than the single $2 \mu \mathrm{L}$ droplet, the drying time of sprayed water layers is significantly shorter than that of the $2 \mu \mathrm{L}$ droplet. The drying time of sprayed water layer is thus dependent on material wettability, water droplet size and ambient conditions.

\subsection{Antibacterial Test}

The antibacterial property of the coating samples was evaluated against $E$. coli by the agar plate counting method. The bacteria grow well on glass samples, and the number of bacterial colonies is reduced for the $\mathrm{Cr}$ film sample. The antibacterial ratio of $\mathrm{S} 0$ is calculated to be $24 \%$ by $\left(N_{\mathrm{g}}-N_{\mathrm{f}}\right) / N_{\mathrm{g}}$ at an action time of $3 \mathrm{~h}$, where $N_{\mathrm{g}}$ and $N_{\mathrm{f}}$ are the colony numbers of glass and $\mathrm{Cr}$ film samples, respectively (Figure 6). This reveals a certain degree of antibacterial property of $\mathrm{Cr}$ elements [6,30]. Bacterial colonies are rarely observed for samples S1.8-S27.7, leading to an antibacterial ratio of 100\% (Figure 6a). This is consistent with the report that the electrodeposited $\mathrm{Cr}-\mathrm{Ag}$ nanocomposite coatings had high antibacterial activity (nearly 100\%) against E. coli and Staphylococcus aureus [20]. E. coli cells can survive at a shorter action time (e.g., $30 \mathrm{~min}$ ) and lower silver content. However, no colonies are observed on the agar plates if the inoculated glass and film samples were exposed to open air in the clean bench for 15 and 30 min during the action period (Figure $6 \mathrm{~b}$ ), due to the short drying time of bacterial suspension. This indicates that ambient conditions, material features and microdroplet hydration state have a great influence on the viability of bacteria and even coronaviruses at the surfaces [31-33]. These factors would be considered in controlling microbial transmission, especially for the public environmental facilities.
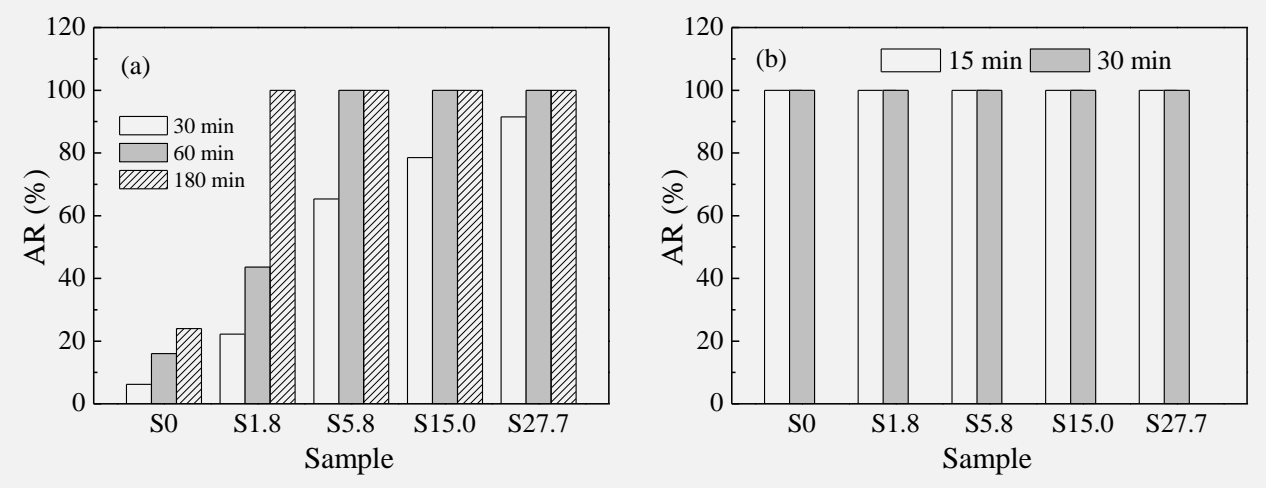

Figure 6. Antibacterial ratio of the film samples tested by agar plate counting method at $20{ }^{\circ} \mathrm{C}$ : (a) closed wet conditions, (b) open-air conditions.

\section{Conclusions}

The Cr-Ag films with Ag content up to 39.2 at.\% were deposited by the magnetron sputtering technique. The films consist of $\mathrm{Cr}$ and $\mathrm{Ag}$ composite and they are relatively flat, without serious silver segregation at the surface. The films are hard, hydrophobic with low surface energy and exhibit excellent antibacterial activity. These features would favor antimicrobial applications of the sputter-deposited $\mathrm{Cr}-\mathrm{Ag}$ films.

Author Contributions: Conceptualization, P.S., Y.H. and T.F.; methodology, L.W. and Y.W.; validation, Y.W.; formal analysis, T.F. and Y.H.; investigation, T.F.; resources, T.F., Y.H. and P.S.; data curation, T.F.; writing—original draft preparation, T.F. and Y.H.; writing—review and editing, T.F.; supervision, P.S.; project administration, T.F.; funding acquisition, T.F. All authors have read and agreed to the published version of the manuscript.

Funding: This research was funded by the Natural Science Foundation of Shaanxi Province, grant number 2021JM-036. 
Institutional Review Board Statement: Not applicable.

Informed Consent Statement: Not applicable.

Data Availability Statement: The data presented in this study are available on request from the corresponding author.

Acknowledgments: This study was supported by the Natural Science Fund of Shaanxi Province (No. 2021JM-036). The authors would thank Instrumental Analysis Center of Xi'an Jiaotong University for the SEM-EDX analyses.

Conflicts of Interest: We declare that we have no conflict of interest.

\section{References}

1. Chang, T.; Sepati, M.; Herting, G.; Leygraf, C.; Rajarao, G.K.; Butina, K.; Richter-Dahlfors, A.; Blomberg, E.; Wallinder, I.O. A novel methodology to study antimicrobial properties of high-touch surfaces used for indoor hygiene applications-A study on $\mathrm{Cu}$ metal. PLoS ONE 2021, 16, e0247081. [CrossRef] [PubMed]

2. Fontes, D.; Reyes, J.; Ahmed, K.; Kinzel, M. A study of fluid dynamics and human physiology factors driving droplet dispersion from a human sneeze. Phys. Fluids 2020, 32, 111904. [CrossRef] [PubMed]

3. Redfern, J.; Tucker, J.; Simmons, L.M.; Askew, P.; Stephan, I.; Verran, J. Environmental and experimental factors affecting efficacy testing of nonporous plastic antimicrobial surfaces. Methods Protoc. 2018, 1, 36. [CrossRef]

4. Connelly, M.C.; Reddy, G.S.; Nadagouda, M.N.; Sekhar, J.A. Antimicrobial and anticorrosive efficacy of inorganic nanoporous surfaces. Clean Technol. Environ. Policy 2017, 19, 845-857. [CrossRef]

5. Kawakami, H.; Yoshida, K.; Nishida, Y.; Kikuchi, Y.; Sato, Y. Antibacterial properties of metallic elements for alloying evaluated with application of JIS Z 2801:2000. ISIJ Int. 2008, 48, 1299-1304. [CrossRef]

6. Cazalini, E.M.; Miyakawa, W.; Teodoro, G.R.; Sobrinho, A.S.S.; Matieli, J.E.; Massi, M.; Koga-Ito, C.Y. Antimicrobial and antibiofilm properties of polypropylene meshes coated with metal-containing DLC thin films. J. Mater. Sci. Mater. Med. 2017, $28,97$. [CrossRef]

7. Nguyen, V.Q.; Ishihara, M.; Kinoda, J.; Hattori, H.; Nakamura, S.; Ono, T.; Miyahira, Y.; Matsui, T. Development of antimicrobial biomaterials produced from chitin-nanofiber sheet/silver nanoparticle composites. J. Nanobiotechnol. 2014, 12, 49. [CrossRef]

8. Zhao, Y.; Xu, J.; Li, Z.; Fu, T.; Jiang, S. In vitro antibacterial properties of $\mathrm{MoO}_{3} / \mathrm{SiO}_{2} / \mathrm{Ag}_{2} \mathrm{O}$ nanocomposite coating prepared by double cathode glow discharge technique. Surf. Coat. Technol. 2020, 397, 125992. [CrossRef]

9. Dinca, P.; Butoi, B.; Lungu, M.; Porosnicu, C.; Jepu, I.; Staicu, C.; Lungu, C.P.; Niculescu, A.; Burducea, I.; Trusca, O.; et al. Antibacterial efficiency of stainless-steel grids coated with $\mathrm{Cu}-\mathrm{Ag}$ by thermionic vacuum arc method. Coatings 2020, 10, 322. [CrossRef]

10. Wojcieszak, D.; Mazur, M.; Kaczmarek, D.; Mazur, P.; Szponar, B.; Domaradzki, J.; Kepinski, L. Influence of the surface properties on bactericidal and fungicidal activity of magnetron sputtered Ti-Ag and Nb-Ag thin films. Mater. Sci. Eng. C 2016, 62, 86-95. [CrossRef] [PubMed]

11. Alias, R.; Mahmoodian, R.; Genasan, K.; Vellasamy, K.M.; Abd Shukor, M.H.; Kamarul, T. Mechanical, antibacterial, and biocompatibility mechanism of PVD grown silver-tantalum-oxide-based nanostructured thin film on stainless steel 316L for surgical applications. Mater. Sci. Eng. C 2020, 107, 110304. [CrossRef] [PubMed]

12. Ferreri, I.; Calderon, S.V.; Escobar Galindo, R.; Palacio, C.; Henriques, M.; Piedade, A.P.; Carvalho, S. Silver activation on thin films of Ag-ZrCN coatings for antimicrobial activity. Mater. Sci. Eng. C 2015, 55, 547-555. [CrossRef] [PubMed]

13. Wang, L.J.; Zhang, F.; Fong, A.; Lai, K.M.; Shum, P.W.; Zhou, Z.F.; Gao, Z.F.; Fu, T. Effects of silver segregation on sputter deposited antibacterial silver-containing diamond-like carbon films. Thin Solid Film. 2018, 650, 58-64. [CrossRef]

14. Cloutier, M.; Turgeon, S.; Busby, Y.; Tatoulian, M.; Pireaux, J.J.; Mantovani, D. Controlled distribution and clustering of silver in Ag-DLC nanocomposite coatings using a hybrid plasma approach. ACS Appl. Mater. Interfaces 2016, 8, 21020-21027. [CrossRef] [PubMed]

15. Swiatek, L.; Olejnik, A.; Grabarczyk, J.; Jedrzejczak, A.; Sobczyk-Guzenda, A.; Kaminska, M.; Jakubowski, W.; Szymanski, W.; Bociaga, D. Multi-doped diamond like-carbon coatings (DLC-Si/Ag) for biomedical applications fabricated using the modified chemical vapour deposition method. Diam. Relat. Mater. 2016, 67, 54-62. [CrossRef]

16. Rashid, S.; Sebastiani, M.; Mughal, M.Z.; Daniel, R.; Bemporad, E. Influence of the silver content on mechanical properties of Ti-Cu-Ag thin films. Nanomaterials 2021, 11, 435. [CrossRef]

17. Bai, L.; Hang, R.; Gao, A.; Zhang, X.; Huang, X.; Wang, Y.; Tang, B.; Zhao, L.; Chu, P.K. Nanostructured titanium-silver coatings with good antibacterial activity and cytocompatibility fabricated by one-step magnetron sputtering. Appl. Surf. Sci. 2015, 355, 32-44. [CrossRef]

18. Wang, L.J.; Zhang, F.; Fong, A.; Lai, K.M.; Shum, P.W.; Zhou, Z.F.; Fu, T.; Ning, P.; Yang, S.Y. Tungsten film as a hard and compatible carrier for antibacterial agent of silver. J. Mater. Sci. 2018, 53, 10640-10652. [CrossRef]

19. Karami, A.; Zhang, H.; Pederick, V.G.; McDevitt, C.A.; Kabir, M.S.; Xu, S.; Munroe, P.; Zhou, Z.; Xie, Z. Cr-Ag coatings: Synthesis, microstructure and antimicrobial properties. Surf. Eng. 2019, 35, 596-603. [CrossRef] 
20. Mendez-Albores, A.; Gonzalez-Arellano, S.G.; Reyes-Vidal, Y.; Torres, J.; Talu, S.; Cercado, B.; Trejo, G. Electrodeposited chrome/silver nanoparticle (Cr/AgNPs) composite coatings: Characterization and antibacterial activity. J. Alloys Compd. 2017, 710, 302-311. [CrossRef]

21. Campos, M.D.; Zucchi, P.C.; Phung, A.; Leonard, S.N.; Hirsch, E.B. The activity of antimicrobial surfaces varies by testing protocol utilized. PLoS ONE 2016, 11, e0160728. [CrossRef]

22. Ma, X.Y. Evaporating Process of Nanofluid Sessile Droplet and Deposition Patterns of Nanoparticles; Tianjin University of Commerce: Tianjin, China, 2016. (In Chinese)

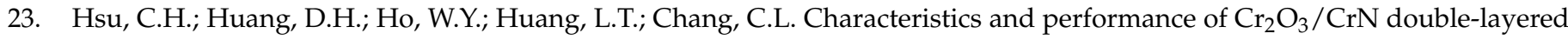
coatings deposited by cathodic arc plasma deposition. Mater. Sci. Eng. A 2006, 429, 212-218. [CrossRef]

24. Cheng, W.L.; Zhou, Z.F.; Shum, P.W.; Li, K.Y. Effect of Ni addition on the structure and properties of Cr-Ni-N coatings deposited by closed-field unbalanced magnetron sputtering ion plating. Surf. Coat. Technol. 2013, 229, 84-89. [CrossRef]

25. Rebelo, R.; Calderon, S.V.; Fangueiro, R.; Henriques, M.; Carvalho, S. Influence of oxygen content on the antibacterial effect of Ag-O coatings deposited by magnetron sputtering. Surf. Coat. Technol. 2016, 305, 1-10. [CrossRef]

26. Lan, W.-C.; Ou, S.-F.; Lin, M.-H.; Ou, K.-L.; Tsai, M.-Y. Development of silver-containing diamond-like carbon for biomedical applications. Part I: Microstructure characteristics, mechanical properties and antibacterial mechanisms. Ceram. Int. 2013, 39, 4099-4104. [CrossRef]

27. Cunliffe, D.; Smart, C.A.; Alexander, C.; Vulfson, E.N. Bacterial adhesion at synthetic surfaces. Appl. Environ. Microbiol. 1999, 65, 4995-5002. [CrossRef] [PubMed]

28. Echeverry-Rendon, M.; Galvis, O.; Aguirre, R.; Robledo, S.; Guillermo Castano, J.; Echeverria, F. Modification of titanium alloys surface properties by plasma electrolytic oxidation (PEO) and influence on biological response. J. Mater. Sci. Mater. Med. 2017, 28, 169. [CrossRef]

29. Geng, J.T.; Li, X.Y.; Xing, G.L.; Sun, G.Q.; Yi, B.K. An experimental study on water surface evaporation rate. Chin. J. Power Sources 2010, 34, 470-472. (In Chinese)

30. Jelinek, M.; Kocourek, T.; Zemek, J.; Miksovsky, J.; Kubinova, S.; Remsa, J.; Kopecek, J.; Jurek, K. Chromium-doped DLC for implants prepared by laser-magnetron deposition. Mater. Sci. Eng. C. 2015, 46, 381-386. [CrossRef]

31. Aboubakr, H.A.; Sharafeldin, T.A.; Goyal, S.M. Stability of SARS-CoV-2 and other coronaviruses in the environment and on common touch surfaces and the influence of climatic conditions: A review. Transbound. Emerg. Dis. 2021, 68, 296-312. [CrossRef] [PubMed]

32. Niu, L.; Liang, W.; Wang, X.; Mu, Y.; Wang, J.; Wu, D.; Zhao, X. Analysis of factors affecting virus survival on object surface and in air. Res. Environ. Sci. 2020, 33, 1589-1595.

33. Fedorenko, A.; Grinberg, M.; Orevi, T.; Kashtan, N. Survival of the enveloped bacteriophage Phi6 (a surrogate for SARS-CoV-2) in evaporated saliva microdroplets deposited on glass surfaces. Sci. Rep. 2020, 10, 22419. [CrossRef] [PubMed] 